\title{
Evidence for phytoplankton iron limitation in the southern California Current System
}

\author{
Andrew L. King ${ }^{*}$, Katherine Barbeau \\ Geosciences Research Division, Scripps Institution of Oceanography, Mail Code 0218, 9500 Gilman Drive, La Jolla, \\ California 92093-0218, USA
}

\begin{abstract}
Observations of phytoplankton iron limitation in the world's oceans have primarily been confined to high-nutrient, low-chlorophyll (HNLC) regimes, found in the western equatorial and subarctic Pacific, Southern Ocean, and coastal upwelling zones off California and Peru. We investigated the potential for phytoplankton iron limitation in coastal transition zones (50 to $200 \mathrm{~km}$ offshore) of the southern California Current System, a weak upwelling regime that is relatively low in nutrients

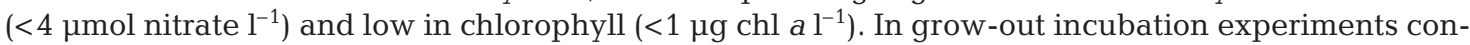
ducted during summer, July 2003 and 2004, phytoplankton responded to nanomolar iron additions, despite the non-HNLC initial conditions. Observed changes in phytoplankton and nutrient parameters upon iron addition were significant, although markedly lower in amplitude relative to typical grow-out experiments in HNLC regimes. While we cannot disprove alternate explanations for the observed limitation of phytoplankton growth, such as a proximate grazing control, our results indicate that phytoplankton growth in the southern California Current System is, at times, limited by the supply of iron. Based on our findings and the results of previous studies in this region, we suggest that phytoplankton biomass is generally limited by the supply of nitrate, while iron, directly or indirectly, influences macronutrient utilization, community species composition, and phytoplankton spatial and temporal distribution.
\end{abstract}

KEY WORDS: Phytoplankton · Limitation · Iron · Trace metals · California Current

\section{INTRODUCTION}

About $30 \%$ of the world's oceans are described as high-nutrient, low-chlorophyll (HNLC) regimes, where phytoplankton standing stock is low and upwelled macronutrients persist in the euphotic zone, typically $\sim 6$ to $25+\mu$ mol nitrate $\mathrm{l}^{-1}$ (e.g. Martin et al. 1989, de Baar et al. 1990). The persistence of macronutrients in oceanic HNLC regimes (e.g. the equatorial and subarctic Pacific Ocean, and the Southern Ocean) has been explained by the slow net growth of phytoplankton due to limitation by a low supply of iron and proximate control from grazers (Martin et al. 1989, Cullen 1991, Miller et al. 1991, Landry et al. 1997). Similar to oceanic HNLC regimes, iron-limited HNLC conditions in the central and northern California Current System (CCS) and the Peru Upwelling Eastern Boundary Current (EBC) systems have been explained by a low sup- ply of iron relative to macronutrients during intense upwelling in summer (Hutchins \& Bruland 1998, Bruland et al. 2001, Johnson et al. 2001, Hutchins et al. 2002, Firme et al. 2003, Fitzwater et al. 2003). EBC systems are traditionally thought to be very productive primarily due to the large flux of upwelled macronutrients nitrate, phosphate, and orthosilicic acid to the euphotic zone, but it is now apparent that iron can limit phytoplankton growth in such upwelling systems, to varying degrees (Hutchins et al. 1998).

Phytoplankton iron limitation is thus commonly associated with oceanic and coastal regimes with high macronutrient concentrations. The concept of iron limitation could readily be extended, however, to regions of significantly lower macronutrient concentrations (e.g. $<6 \mu$ mol nitrate $\mathrm{l}^{-1}$ ), provided that macronutrients exceed the corresponding iron required for phytoplankton growth. The mesotrophic southern 


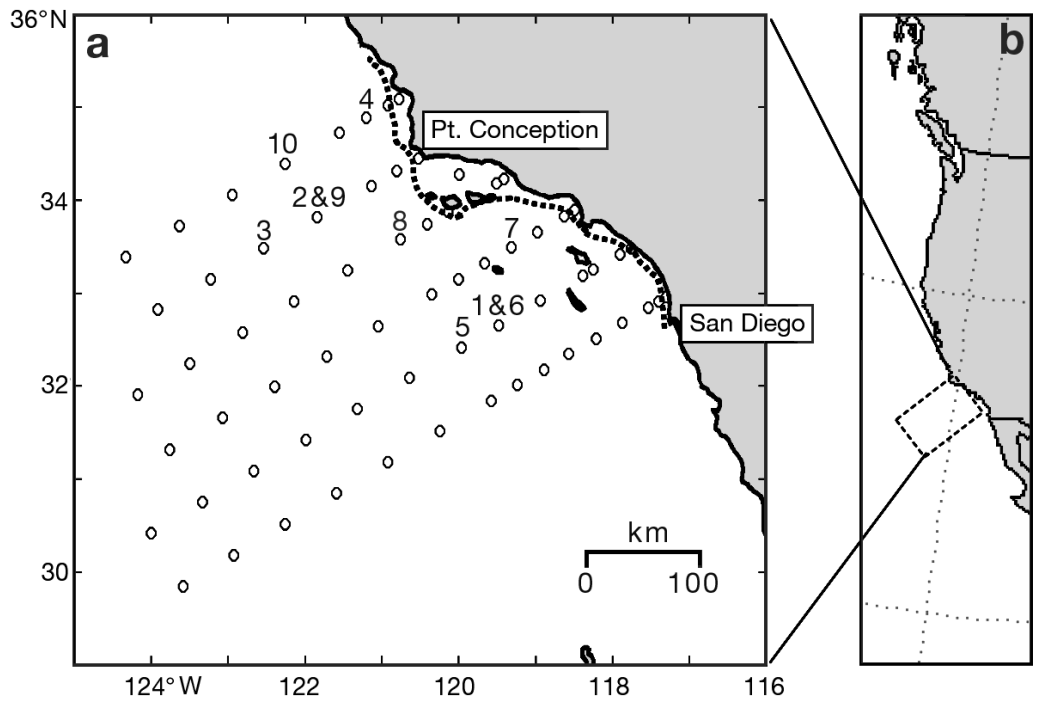

Fig. 1. (a) The study region of the California Cooperative Fisheries Investigations is approximately $175000 \mathrm{~km}^{2}$ and includes 66 stations (marked with open circles). For line and station nomenclature, refer to station map at www.calcofi.org. Station locations of iron addition incubation experiments conducted in July 2003 are marked 1 to 4, corresponding to Expts 03-1, 03-2, 03-3, and 03-4, respectively (see Table 2). Experiments conducted in July 2004 are marked 5 to 10 and correspond to Expts 04-1, 042, 04-3, 04-4, 04-5, and 04-6, respectively (see Table 2). The black dashed line marks the $200 \mathrm{~m}$ isobath. San Diego and Point Conception, California, USA, are labeled for geographic reference. (b) The southern California Current System is in the temperate northeastern Pacific Ocean, off the western coast of North America

CCS, extending from the United States/Mexican border to Point Conception, California (Fig. 1), might be one such regime. Previous survey cruises in the region have observed the presence of nitrate in surface waters, with corresponding low phytoplankton biomass (www.calcofi.org). In comparison to the central and northern CCS (central California up to Oregon) and oceanic HNLC regimes, the southern CCS is a weaker upwelling regime (mean nitrate at $10 \mathrm{~m}$ between 1985 and 2005 was only $0.7 \mu_{\text {mol l}}{ }^{-1}$; www.calcofi.org). The southern CCS spans a range of apparent water masses, from episodic upwelling nearshore, to a transition zone composed of upwelled and California Current waters, to oligotrophic waters offshore (Hayward \& Venrick 1998). The region is generally described as being nitrate limited, as evinced by the general absence of nitrate and presence of phosphate and silicate in the euphotic zone, and the deepwater nitrate-phosphate relationship, the slope of which predicts the depletion of nitrate before phosphate (Ryther \& Dunston 1971). Further, observations and experiments conducted over several decades have indicated that phytoplankton standing stock and productivity in southern CCS surface waters is positively correlated to the concentration of nitrate (Eppley et al.
1979, Eppley \& Holm-Hansen 1986, Hayward \& Venrick 1998).

Recent observations of phytoplankton iron limitation in central and northern California nearshore waters (i.e. within several kilometers from shore; Johnson et al. 1997, Hutchins et al. 1998) suggest that, in addition to nitrate, iron might play a larger role than previously considered in the southern CCS. We investigated the potential influence of iron on phytoplankton growth and community structure in the southern CCS on a large spatial scale, ranging between San Diego and Avila Beach, California, and spanning from the coastal nearshore to the coastal transition zone, $\sim 50$ to $200 \mathrm{~km}$ offshore. Here, we present results from iron addition grow-out bottle incubation experiments conducted in July 2003 and 2004 in the southern CCS. Experiments were conducted in water masses that were relatively low in nutrients $\quad<3.5 \mu \mathrm{mol}$ nitrate $\left.\mathrm{l}^{-1}\right)$, low in chlorophyll a $(<0.7 \mu \mathrm{g}$ chl a $\mathrm{l}^{-1}$ ), and low in dissolved iron

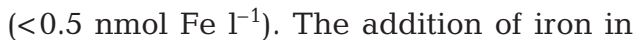
grow-out bottle experiments stimulated phytoplankton growth and nitrate depletion, and resulted in a shift in phytoplankton community structure. Our data indicate that, in some parts of the southern CCS during summertime, iron was a limiting factor for phytoplankton growth, while the phytoplankton standing stock was limited by nitrate.

\section{MATERIALS AND METHODS}

Study site. The southern CCS (see Fig. 1) is the site under study in the $>50$ yr California Cooperative Oceanic Fisheries Investigations (CalCOFI; www.calcofi.org) continuous time series and the recently established California Current Ecosystem Long-Term Ecological Research (cce.lternet.edu) program. The pelagic ecosystem is mesotrophic, on average: low nutrient, low phytoplankton biomass, oligotrophic conditions are perturbed by episodic spring and summer wind-driven upwelling events, which result in high nutrient concentrations and phytoplankton biomass (Eppley at al. 1979, Jones et al. 1983). In comparison to other EBC systems, wind-driven upwelling in the southern CCS is generally weaker and exhibits less seasonal variability, because of the physical sheltering of upwelling favorable winds by Point Conception (Nelson 1977). Generally, upwelling-favorable winds occur during spring and summer, and force coastal 
Ekman upwelling $(<10 \mathrm{~km}$ from shore) and Ekman pumping (wind stress curl upwelling) in the offshore coastal transition zone (Chelton 1982, Winant \& Dorman 1997).

The CalCOFI program has focused on the southern CCS in a continuing effort to understand natural biological variability, especially stocks of epipelagic fish such as sardine and anchovy. The study area investigated by the program since 1984 extends from the United States/Mexican border to Avila Beach, California (just north of Point Conception), and consists of 6 transects, which reach $\sim 350 \mathrm{~km}$ offshore Point Conception and $\sim 700 \mathrm{~km}$ offshore San Diego, California (station plan shown in Fig. 1). The stations are evenly spaced $\sim 70 \mathrm{~km}$ apart in the offshore regions (more than $\sim 100$ to $200 \mathrm{~km}$ from the coast) and $<35 \mathrm{~km}$ apart in the nearshore regions. Plots of synoptic conditions during research cruises in July 2003 and 2004 of temperature, salinity, nitrate, and chl a were constructed using data provided by the CalCOFI program. The CalCOFI time series also measures dissolved oxygen, nitrite, phosphate, orthosilicic acid, macrozooplankton biomass, and, at select stations, ${ }^{14} \mathrm{C}$-based primary productivity.

Iron addition grow-out experiments. Ten shipboard iron addition grow-out incubation experiments were conducted on 2 CalCOFI cruises within the southern CCS during 17 to 31 July 2003 and 15 to 28 July 2004. Experiments were set up at stations where in vivo chl a and nitrate concentrations (as determined by spectrophotometry) indicated potential iron limitation,

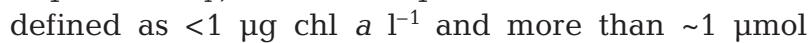
nitrate $\mathrm{l}^{-1}$ in surface waters. Seawater from the mixed layer ( 5 to $10 \mathrm{~m}$ depth) was collected using trace metal clean techniques with a Teflon diaphragm pumping system and dispensed into 2.71 polycarbonate bottles. Experimental treatments included either duplicate (July 2004) or triplicate (July 2003) unamended controls and additions of iron to $5 \mathrm{nmol}^{-1}$ from a stock of $\mathrm{FeCl}_{3}$ in $0.1 \mathrm{~mol} \mathrm{l}^{-1}$ ultrapure $\mathrm{HCl}$ (OmniTrace Ultra, EMD Chemicals). Experiments were placed in deckboard incubators cooled by flow-through seawater at $35 \%$ of incident light. The setup and sampling of all experiments were carried out under Class 100 laminar flow hoods and in positive-pressure clean areas. Experimental equipment was handled with vinyl gloves and cleaned using $\mathrm{HCl}$ and $\mathrm{HNO}_{3}$ (TraceMetal grade, Fisher Chemicals), with a final ultrapure $\mathrm{HCl}$ rinse. Ultrapure Milli-Q water (Millipore) was used for soaking and rinsing of all equipment.

Experiments were sampled daily for chl a $(0.7 \mu \mathrm{m}$ Whatman GF/F filters), macronutrients, and microscopy. Periodically, samples were taken for carotenoid pigments and particulate organic carbon (POC) and nitrogen (PON). Chl a was analyzed using standard fluorometric methods (Strickland \& Parsons 1972). Carotenoid pigments were separated via reverse phase HPLC and detected with an ultraviolet/visible spectrophotometer (Goericke \& Montoya 1998). Phytoplankton samples for microscopy were preserved in $1 \%$ filtered sodium tetraborate decahydrate-buffered formalin and enumerated with a Zeiss inverted microscope using Utermöhl settling chambers (1 to $30 \mathrm{ml}$ ). Samples for macronutrients were frozen, and concentrations of nitrate $\left(\mathrm{NO}_{3}{ }^{-}\right)$, phosphate $\left(\mathrm{PO}_{4}{ }^{2-}\right)$, and orthosilicic acid $\mathrm{Si}(\mathrm{OH})_{4}$, were determined colorimetrically by an automated analyzer (Oceanographic Data Facility, La Jolla, California and Marine Science Institute, Santa Barbara, California). POC and PON were vacuum filtered onto precombusted $0.7 \mu \mathrm{m}$ Whatman GF/F filters and measured using a carbon/hydrogen/nitrogen (CHN) analyzer (Scripps Institution of Oceanography Analytical Facility, La Jolla, California).

Changes in some experimental parameters from control and iron-added incubations were analyzed as a normalized response - the ratio of a parameter in ironadded replicates and control replicates at the final time point $\left(t_{\text {final }}\right)$. For example, a 1.0 -fold response indicates that iron addition had no effect on a parameter. A 1.5fold response indicates that after iron addition, a parameter was $50 \%$ greater relative to control replicates. This is similar to the iron limitation indices calculated by Firme et al. (2003).

Analysis of dissolved iron. Dissolved iron was measured in seawater collected for all experiments. Samples for dissolved iron were filtered using $0.4 \mu \mathrm{m}$ acid-cleaned polycarbonate filters, acidified to $\mathrm{pH} 1.7$ to 1.8 with ultrapure $\mathrm{HCl}$, and stored in acid-cleaned, low-density polyethylene bottles for 6 mo or longer. Dissolved iron concentration was determined using an FeLume flow injection analysis system (Waterville Analytical), using a method modified from Bowie et al. (1998). Reagents used were ultrapure Milli-Q water (Millipore), sodium sulfite (Sigma Ultra, SigmaAldrich), ultrapure $\mathrm{HCl}$, ultrapure $\mathrm{NH}_{3} \mathrm{OH}$ (OmniTrace Ultra, EMD Chemicals), ultrapure glacial acetic acid (Optima, Fisher Scientific), and luminol sodium salt (5-amino-2, 3-dihydro-1,4-phthalazinedione; SigmaAldrich). A $2 \mathrm{~mol} \mathrm{l}^{-1}$ ammonium acetate buffer was made by diluting $\mathrm{NH}_{3} \mathrm{OH}$ in Milli-Q water and slowly adding glacial acetic acid. An $\mathrm{NH}_{3} \mathrm{OH}$ buffer was made by diluting $\mathrm{HCl}$ in Milli-Q water and adding $\mathrm{NH}_{3} \mathrm{OH}$ (final concentration was $0.5 \mathrm{~mol} \mathrm{l}^{-1} \mathrm{HCl}$ and $1 \mathrm{~mol} \mathrm{l}^{-1} \mathrm{NH}_{3} \mathrm{OH}, \mathrm{pH}$ 9.5). The reagents were not purified further.

Iron in seawater samples was reduced to iron(II) for $12 \mathrm{~h}$ by adding sodium sulfite to a final concentration of $2 \mu \mathrm{mol}^{-1}$, buffered to $\mathrm{pH} \sim 5.8$ in-line with the addition of ammonium acetate, and preconcentrated on a column (85 $\mu \mathrm{l}$ internal volume; Global FIA) filled with 
nitriloacetic acid resin (NTA Superflow, Qiagen; Lohan

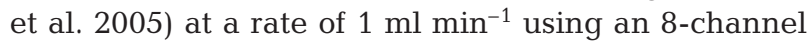
peristaltic pump (Rainin Instrument). Iron(II) was eluted with $0.14 \mathrm{~mol} \mathrm{l}^{-1} \mathrm{HCl}$ carrier solution (at $2 \mathrm{ml}$ $\mathrm{min}^{-1}$ ) and mixed in a glass reaction coil with the $\mathrm{NH}_{3} \mathrm{OH}$ buffer (at $2 \mathrm{ml} \mathrm{min}^{-1}$ ); the reaction $\mathrm{pH}$ of the carrier/luminol-ammonia mixture was $~ 9.3$. Radicals produced by the oxidation of iron(II) to iron(III) catalyzed the oxidation of luminol and produced light at $426 \mathrm{~nm}$, which was detected by a photomultiplier tube (Hamamatsu Photonics). Iron(II) was determined by measuring peak height with standard addition methodology. The detection limit (3-fold the standard deviation) for this method was as low as $20 \mathrm{pmol}^{-1}$, and precision (relative standard deviation) was as low as $1.4 \%$ (Table 1). Using this method, standards from the sampling and analysis of Fe (SAFe) intercomparison cruise in October 2004 were measured to be $0.10 \pm 0.02 \mathrm{nmol}$ Fe $\mathrm{l}^{-1}$ (Surface bottle 279, mean $\pm 1 \mathrm{SD}, \mathrm{n}=4$ ) and $0.92 \pm 0.03 \mathrm{nmol} \mathrm{Fe}^{-1}$ (Deep2 bottle 285, mean $\pm 1 \mathrm{SD}$, $\mathrm{n}=4)$. The consensus value of the surface standard is $0.097 \pm 0.043(\mathrm{n}=140) \mathrm{nmol} \mathrm{Fe} \mathrm{l}^{-1}$ and the deep standard is $0.91 \pm 0.17(\mathrm{n}=168) \mathrm{nmol} \mathrm{Fe} \mathrm{l}^{-1}$ (Johnson et al. 2007; SAFe standards and further information available by email from requestsafestandard@ucsc.edu).

\section{RESULTS}

\section{Hydrographic setting}

Synoptic surface conditions of the region and the locations of iron addition incubation experiments conducted in July 2003 and 2004 are shown in Fig. 2 and Table 2. In both 2003 and 2004, upwelling was generally indicated by the presence of nitrate and cooler temperatures at the sea surface. The association of elevated surface nitrate with higher salinity waters was less clear because of the presence of a nearshore pool

Table 1. Analytical figures of merit for iron analysis. The analytical blank is measured as the sum of reagent iron concentrations (buffers, hydrochloric acid, sulfite). Listed are means and standard deviations ( $\mathrm{SD}_{i} \mathrm{nmol} \mathrm{Fe} \mathrm{l}^{-1}$ ), detection limits (DL, defined as 3 times the standard deviation of 3 replicate measurements; nmol $\mathrm{Fe} \mathrm{l}^{-1}$ ), and relative standard deviations (RSD, defined as the standard deviation divided by the mean)

\begin{tabular}{|lcc|}
\hline & Blank & Seawater \\
\hline Mean \pm SD & $0.13 \pm 0.01$ & - \\
DL mean & 0.04 & 0.07 \\
DL range & $0.02-0.05$ & $0.02-0.12$ \\
RSD mean (\%) & 7.4 & 6.5 \\
RSD range (\%) & $3.6-13.8$ & $1.4-23.6$ \\
\hline
\end{tabular}

of warm, 233.4 to $33.5 \mathrm{psu}$ water in the southeastern portion of the region, which was approximately the same salinity as upwelled waters (e.g. Lynn \& Simpson 1987). Nitrate was generally depleted in surface waters along the coast in the central and southern portion of the study area and well offshore. Nitrate was typically present $\left(\sim 3\right.$ to $8 \mu \mathrm{mol} \mathrm{l^{-1 } )}$ near Pt. Conception and in the coastal transition zone between 50 and $200 \mathrm{~km}$ offshore. Time-series wind records obtained from buoys indicated that wind stress fields were equatorward (upwelling favorable) both preceding and during the cruises (National Oceanic and Atmospheric Administration National Buoy Data Center: www.ndbc.noaa. gov). Wind data from the shipboard meteorological system were somewhat biased because of the time lag between stations, but confirmed a pattern similar to that reported by buoys in the survey region.

\section{Iron addition grow-out incubations}

The initial conditions $\left(t_{0}\right)$ at 10 stations where seawater for experiments was collected for iron addition incubations ranged from 0.23 to $0.65 \mu \mathrm{g}$ chl a $\mathrm{l}^{-1}, 0.90$ to $3.50 \mu \mathrm{mol}$ nitrate $\mathrm{l}^{-1}$, and 0.05 to $0.46 \mathrm{nmol}$ dissolved $\mathrm{Fe} \mathrm{l}^{-1}$ (Table 2). The concentrations of chl $a$, macronutrients, POC, and PON are shown for control and iron addition experiments at $t_{\text {final }}$ in Table 2. Nitrate was depleted more rapidly in iron-added replicates relative to controls (up to 2.7 -fold), concomitant with an increase in chl a in iron-added replicates by 1.2- to 3.4 -fold relative to controls (Table 3 ). In experiments from July 2003, nitrate depletion and chl a increase were significantly greater in iron-added replicates as determined by a paired $t$-test $(\mathrm{p}<0.001, \mathrm{n}=3$; paired $t$-test comparisons of July 2004 experimental results are not possible since experiments were conducted in duplicate, although the differences in means of control and iron-added replicates were always greater than their respective standard deviations). Some iron-added replicates accumulated up to 1.9-fold more POC and PON relative to controls (Table 3 ). In certain cases (Expts 03-1, 04-1, 04-3, and 04-5), iron addition resulted in an increase in POC, but not in PON. Changes in the macronutrients phosphate and orthosilicic acid were variable and sometimes difficult to resolve due to large relative standard deviations, though the general trend for phosphate (except Expts 04-2, 04-3, and 04-6), and in some cases orthosilicic acid, was a greater drawdown in iron-added replicates compared to controls (Table 2).

HPLC-determined carotenoid pigments indicated that the initial phytoplankton community was diverse - the largest contributor to total carotenoid pigments was $19^{\prime}$-hexanoyloxyfucoxanthin (38 to $57 \%$ of 

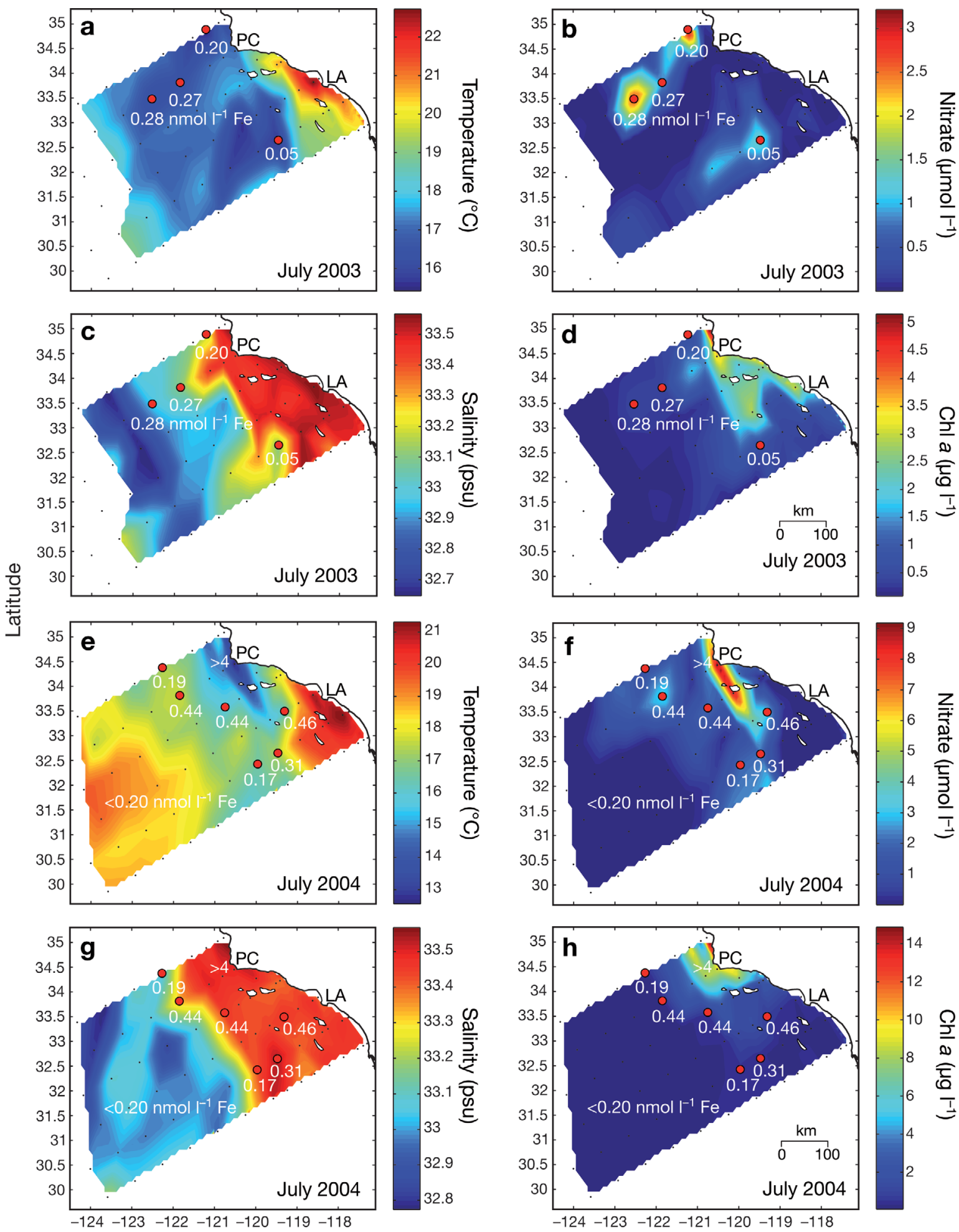

Longitude

Fig. 2. (a to d) Synoptic conditions in the southern California Current System (CCS) at 10 m during July 2003: (a) water temperature $\left({ }^{\circ} \mathrm{C}\right)$, (b) nitrate $\left(\mu \mathrm{mol} \mathrm{l}^{-1}\right)$, (c) salinity (psu), and (d) chl a ( $\left.\mathrm{gg} \mathrm{l}^{-1}\right)$. (e to h) Synoptic conditions in the southern CCS at $10 \mathrm{~m}$ during July 2004: (e) water temperature $\left({ }^{\circ} \mathrm{C}\right)$, (f) nitrate $\left(\mu \mathrm{mol} \mathrm{l}^{-1}\right)$, (g) salinity $(\mathrm{psu})$, and $(\mathrm{h}) \mathrm{chl} \mathrm{a}\left(\mu \mathrm{g} \mathrm{l}^{-1}\right)$. Data in each plot were interpolated between stations marked with black dots. Dissolved iron concentrations (nmol $\mathrm{l}^{-1}$ ) are noted on panels. Stations where phytoplankton responded to iron addition in bottle experiments are indicated with solid red circles and are described in Table 2. For geographic reference, Point Conception (PC) and Los Angeles (LA), California, USA are labeled in each panel 
Table 2. For iron addition experiments, the table lists (from top to bottom): experiment name and the corresponding CalCOFI station reference number (see www.calcofi.org for station locations), date (mm/dd/yy) and local time ( $\mathrm{h}$; Pacific Standard Time) the experiment began, latitude (Lat) and longitude (Long) of the station, bottom depth $(\mathrm{m})$, and distance offshore (km). Parameters at $t_{0}$ are listed for: dissolved iron $\left(\mathrm{DFe}_{;} \mathrm{nmol} \mathrm{l^{-1 }}\right)$, chlorophyll a $\left(\mathrm{Chl} a_{;} \mu \mathrm{gl}^{-1}\right)$, nitrate $\left(\mathrm{NO}_{3}{ }^{-} ; \mu \mathrm{mol}^{-1}\right)$, phosphate $\left(\mathrm{PO}_{4}{ }^{2-} ; \mu m o l l^{-1}\right)$, or-

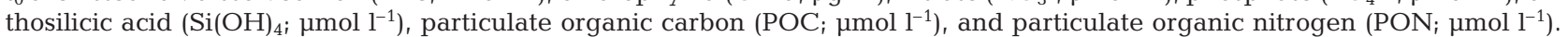

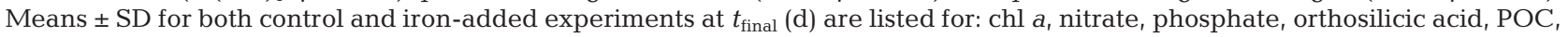
and PON (same units as above) (nd: no data)

\begin{tabular}{|c|c|c|c|c|c|c|c|c|c|c|}
\hline $\begin{array}{l}\text { Expt } \\
\text { CalCOFI station }\end{array}$ & $\begin{array}{c}03-1 \\
90.53\end{array}$ & $\begin{array}{c}03-2 \\
80.70\end{array}$ & $\begin{array}{c}03-3 \\
80.80\end{array}$ & $\begin{array}{c}03-4 \\
77.55\end{array}$ & $\begin{array}{c}04-1 \\
90.60\end{array}$ & $\begin{array}{c}04-2 \\
90.53\end{array}$ & $\begin{array}{r}04-3 \\
87.45\end{array}$ & $\begin{array}{c}04-4 \\
83.60\end{array}$ & $\begin{array}{c}04-5 \\
80.70\end{array}$ & $\begin{array}{c}04-6 \\
77.70\end{array}$ \\
\hline Date & $07 / 21 / 03$ & $07 / 27 / 03$ & 07/27/03 & $07 / 29 / 03$ & $07 / 17 / 04$ & $07 / 17 / 04$ & 07/19/04 & $07 / 23 / 04$ & $07 / 24 / 04$ & $07 / 26 / 04$ \\
\hline Local time & $17: 00$ & 05:00 & $14: 00$ & $13: 30$ & $16: 00$ & $17: 20$ & $17: 00$ & 01:00 & $19: 00$ & $13: 00$ \\
\hline Lat & 32.65 & 33.82 & 33.48 & 34.89 & 32.42 & 32.65 & 33.49 & 33.58 & 33.82 & 34.39 \\
\hline Long & -119.48 & -121.84 & -122.53 & -121.20 & -119.96 & -119.48 & -119.32 & -120.76 & -121.84 & -122.25 \\
\hline Depth & 1320 & 3630 & 3990 & 570 & 895 & 1320 & 1641 & 1400 & 3630 & 4020 \\
\hline Offshore dist. & 155 & 145 & 210 & 50 & 205 & 155 & 75 & 105 & 145 & 155 \\
\hline \multicolumn{11}{|l|}{$t_{0}$} \\
\hline $\mathrm{DFe}$ & 0.05 & 0.27 & 0.28 & 0.20 & 0.17 & 0.31 & 0.46 & 0.44 & 0.44 & 0.19 \\
\hline Chl a & 0.52 & 0.41 & 0.35 & 0.65 & 0.36 & 0.32 & 0.50 & 0.48 & 0.31 & 0.23 \\
\hline $\mathrm{NO}_{3}{ }^{-}$ & 0.90 & 1.78 & 2.20 & 3.50 & 2.04 & 2.12 & 3.17 & 1.97 & 3.35 & 1.66 \\
\hline $\mathrm{PO}_{4}{ }^{2-}$ & 0.43 & 0.40 & 0.57 & 0.54 & 0.30 & 0.30 & 0.40 & 0.30 & 0.30 & 0.30 \\
\hline $\mathrm{Si}(\mathrm{OH})_{4}$ & 0.60 & 1.10 & 2.20 & 1.40 & 0.40 & 0.30 & 1.80 & 0.40 & 1.10 & 1.00 \\
\hline POC & 19.30 & 10.95 & 8.76 & 14.40 & 6.63 & 5.40 & 5.74 & nd & 3.71 & nd \\
\hline PON & 1.92 & 1.71 & 1.25 & 2.68 & 1.02 & 1.16 & 0.88 & nd & 0.45 & nd \\
\hline $\begin{array}{l}\text { Control } \boldsymbol{t}_{\text {final }} \\
t_{\text {final }}\end{array}$ & 1.1 & 2.1 & 2.7 & 2.9 & 2.2 & 1.9 & 2.1 & 1.8 & 3.0 & 2.0 \\
\hline Chl a & $\begin{array}{r}0.90 \\
\pm 0.01\end{array}$ & $\begin{array}{r}0.50 \\
\pm 0.02\end{array}$ & $\begin{array}{r}0.55 \\
\pm 0.03\end{array}$ & $\begin{array}{r}0.55 \\
\pm 0.03\end{array}$ & $\begin{array}{r}0.94 \\
\pm 0.07\end{array}$ & $\begin{array}{r}1.51 \\
\pm 0.01\end{array}$ & $\begin{array}{r}3.48 \\
\pm 0.22\end{array}$ & $\begin{array}{r}0.57 \\
\pm 0.19\end{array}$ & $\begin{array}{r}1.42 \\
\pm 0.14\end{array}$ & $\begin{array}{r}0.66 \\
\pm 0.02\end{array}$ \\
\hline $\mathrm{NO}_{3}{ }^{-}$ & $\begin{array}{r}0.65 \\
\pm 0.02\end{array}$ & $\begin{array}{r}0.77 \\
\pm 0.01\end{array}$ & $\begin{array}{r}1.34 \\
\pm 0.13\end{array}$ & $\begin{array}{r}1.88 \\
\pm 0.07\end{array}$ & $\begin{array}{r}1.22 \\
\pm 0.19\end{array}$ & $\begin{array}{r}0.80 \\
\pm 0.12\end{array}$ & $\begin{array}{r}0.38 \\
\pm 0.12\end{array}$ & $\begin{array}{r}1.33 \\
\pm 0.08\end{array}$ & $\begin{array}{r}1.54 \\
\pm 0.13\end{array}$ & $\begin{array}{l}1.32 \\
\text { nd }\end{array}$ \\
\hline $\mathrm{PO}_{4}{ }^{2-}$ & $\begin{array}{r}0.43 \\
\pm 0.08\end{array}$ & $\begin{array}{r}0.44 \\
\pm 0.06\end{array}$ & $\begin{array}{r}0.50 \\
\pm 0.03\end{array}$ & $\begin{array}{r}0.52 \\
\pm 0.04\end{array}$ & $\begin{array}{r}0.23 \\
\pm 0.00\end{array}$ & $\begin{array}{r}0.20 \\
\pm 0.00\end{array}$ & $\begin{array}{r}0.21 \\
\pm 0.01\end{array}$ & $\begin{array}{r}0.25 \\
\pm 0.01\end{array}$ & $\begin{array}{r}0.26 \\
\pm 0.00\end{array}$ & $\begin{array}{l}0.29 \\
\text { nd }\end{array}$ \\
\hline $\mathrm{Si}(\mathrm{OH})_{4}$ & $\begin{array}{r}0.64 \\
\pm 0.21\end{array}$ & $\begin{array}{r}1.06 \\
\pm 0.16\end{array}$ & $\begin{array}{r}2.00 \\
\pm 0.26\end{array}$ & $\begin{array}{r}0.55 \\
\pm 0.00\end{array}$ & $\begin{array}{r}0.30 \\
\pm 0.34\end{array}$ & $\begin{array}{r}0.08 \\
\pm 0.03\end{array}$ & $\begin{array}{r}0.91 \\
\pm 0.09\end{array}$ & $\begin{array}{r}0.34 \\
\pm 0.06\end{array}$ & $\begin{array}{r}1.06 \\
\pm 0.06\end{array}$ & $\begin{array}{l}0.90 \\
\text { nd }\end{array}$ \\
\hline POC & $\begin{array}{l}19.80^{\mathrm{a}} \\
\pm 2.24\end{array}$ & $\begin{array}{l}17.60 \\
\pm 1.22\end{array}$ & $\begin{array}{l}10.08^{\mathrm{a}} \\
\pm 1.50\end{array}$ & $\begin{array}{l}19.25 \\
\pm 3.32\end{array}$ & $\begin{array}{l}10.99 \\
\pm 0.37\end{array}$ & $\begin{array}{l}11.57 \\
\pm 0.20\end{array}$ & $\begin{array}{l}20.79 \\
\pm 3.60\end{array}$ & $\begin{array}{l}10.07^{\mathrm{a}} \\
\pm 0.53\end{array}$ & $\begin{array}{l}17.10^{\mathrm{a}} \\
\pm 0.11\end{array}$ & $\begin{array}{l}\text { nd } \\
\text { nd }\end{array}$ \\
\hline PON & $\begin{array}{r}2.44^{\mathrm{a}} \\
\pm 0.16\end{array}$ & $\begin{array}{r}1.51 \\
\pm 0.04\end{array}$ & $\begin{array}{r}1.58^{\mathrm{a}} \\
\pm 0.22\end{array}$ & $\begin{array}{r}3.56 \\
\pm 0.67\end{array}$ & $\begin{array}{r}1.82 \\
\pm 0.08\end{array}$ & $\begin{array}{r}1.66 \\
\pm 0.00\end{array}$ & $\begin{array}{r}2.57 \\
\pm 0.53\end{array}$ & $\begin{array}{r}1.52^{\mathrm{a}} \\
\pm 0.04\end{array}$ & $\begin{array}{r}2.88^{\mathrm{a}} \\
\pm 0.26\end{array}$ & $\begin{array}{l}\text { nd } \\
\text { nd }\end{array}$ \\
\hline $\begin{array}{l}+\mathbf{F e} \boldsymbol{t}_{\text {final }} \\
t_{\text {final }}\end{array}$ & 1.1 & 2.1 & 2.7 & 2.9 & 2.2 & 1.9 & 2.1 & 1.8 & 3.0 & 2.0 \\
\hline Chl a & $\begin{array}{r}1.49 \\
\pm 0.03\end{array}$ & $\begin{array}{r}1.03 \\
\pm 0.24\end{array}$ & $\begin{array}{r}1.46 \\
\pm 0.21\end{array}$ & $\begin{array}{r}1.85 \\
\pm 0.07\end{array}$ & $\begin{array}{r}2.91 \\
\pm 0.52\end{array}$ & $\begin{array}{r}1.97 \\
\pm 0.17\end{array}$ & $\begin{array}{r}5.53 \\
\pm 0.22\end{array}$ & $\begin{array}{r}1.13 \\
\pm 0.03\end{array}$ & $\begin{array}{r}2.13 \\
\pm 0.18\end{array}$ & $\begin{array}{r}0.81 \\
\pm 0.02\end{array}$ \\
\hline $\mathrm{NO}_{3}{ }^{-}$ & $\begin{array}{r}0.32 \\
\pm 0.04\end{array}$ & $\begin{array}{r}0.06 \\
\pm 0.06\end{array}$ & $\begin{array}{r}0.37 \\
\pm 0.15\end{array}$ & $\begin{array}{r}0.00 \\
\pm 0.00\end{array}$ & $\begin{array}{r}0.06 \\
\pm 0.04\end{array}$ & $\begin{array}{r}0.56 \\
\pm 0.02\end{array}$ & $\begin{array}{r}0.05 \\
\pm 0.02\end{array}$ & $\begin{array}{r}0.06 \\
\pm 0.16\end{array}$ & $\begin{array}{l}0.72 \\
\text { nd }\end{array}$ & $\begin{array}{l}1.16 \\
\text { nd }\end{array}$ \\
\hline $\mathrm{PO}_{4}{ }^{2-}$ & $\begin{array}{r}0.29 \\
\pm 0.05\end{array}$ & $\begin{array}{r}0.39 \\
\pm 0.03\end{array}$ & $\begin{array}{r}0.32 \\
\pm 0.09\end{array}$ & $\begin{array}{r}0.36 \\
\pm 0.01\end{array}$ & $\begin{array}{r}0.18 \\
\pm 0.00\end{array}$ & $\begin{array}{r}0.19 \\
\pm 0.00\end{array}$ & $\begin{array}{r}0.21 \\
\pm 0.02\end{array}$ & $\begin{array}{r}0.19 \\
\pm 0.03\end{array}$ & $\begin{array}{l}0.22 \\
\text { nd }\end{array}$ & $\begin{array}{l}0.28 \\
\text { nd }\end{array}$ \\
\hline $\mathrm{Si}(\mathrm{OH})_{4}$ & $\begin{array}{r}0.45 \\
\pm 0.18\end{array}$ & $\begin{array}{r}1.13 \\
\pm 0.11\end{array}$ & $\begin{array}{r}1.20 \\
\pm 0.46\end{array}$ & $\begin{array}{r}0.43 \\
\pm 0.03\end{array}$ & $\begin{array}{r}0.14 \\
\pm 0.03\end{array}$ & $\begin{array}{r}0.14 \\
\pm 0.06\end{array}$ & $\begin{array}{r}0.89 \\
\pm 0.03\end{array}$ & $\begin{array}{r}0.24 \\
\pm 0.17\end{array}$ & $\begin{array}{l}0.43 \\
\text { nd }\end{array}$ & $\begin{array}{l}0.84 \\
\text { nd }\end{array}$ \\
\hline POC & $\begin{array}{l}24.17^{\mathrm{a}} \\
\pm 2.57\end{array}$ & $\begin{array}{l}16.05 \\
\pm 0.59\end{array}$ & $\begin{array}{l}17.94^{\mathrm{a}} \\
\pm 1.09\end{array}$ & $\begin{array}{l}35.07 \\
\pm 1.93\end{array}$ & $\begin{array}{l}15.41 \\
\pm 3.02\end{array}$ & $\begin{array}{l}15.41 \\
\pm 3.02\end{array}$ & $\begin{array}{l}27.52 \\
\pm 1.84\end{array}$ & $\begin{array}{c}20.87^{\mathrm{a}} \\
\pm 3.39\end{array}$ & $\begin{array}{l}23.17^{\mathrm{a}} \\
\pm 2.52\end{array}$ & $\begin{array}{l}\text { nd } \\
\text { nd }\end{array}$ \\
\hline PON & $\begin{array}{r}2.50^{\mathrm{a}} \\
\pm 0.08\end{array}$ & $\begin{array}{r}2.94 \\
\pm 0.13\end{array}$ & $\begin{array}{r}2.74^{\mathrm{a}} \\
\pm 0.17\end{array}$ & $\begin{array}{r}5.29 \\
\pm 0.27\end{array}$ & $\begin{array}{r}1.66 \\
\pm 0.15\end{array}$ & $\begin{array}{r}1.92 \\
\pm 0.15\end{array}$ & $\begin{array}{r}2.57 \\
\pm 0.68\end{array}$ & $\begin{aligned} & 2.94^{\mathrm{a}} \\
\pm & 0.76\end{aligned}$ & $\begin{array}{r}2.90^{\mathrm{a}} \\
\pm 0.57\end{array}$ & $\begin{array}{l}\text { nd } \\
\text { nd }\end{array}$ \\
\hline
\end{tabular}

${ }^{a}$ Because POC and PON samples were not collected daily, $t_{\text {final }}$ for POC and PON were on different days than $t_{\text {final }}$ for other parameters. $t_{\text {final }}$ for POC/PON was $2.1 \mathrm{~d}$ for Expt 03-1, $3.8 \mathrm{~d}$ for Expt 03-3, $2.9 \mathrm{~d}$ for Expt 04-4, and 4.0 d for Expt 04-5

the total carotenoids by mass), a pigment characteristic of prymnesiophytes and diatoms. Fucoxanthin (diatoms) accounted for 12 to $38 \%$ of the total carotenoid pigment mass; 19'-butanoyloxyfucoxanthin (pelago- phytes and chrysophytes) accounted for 9 to $23 \%$; chl $C_{3}$ (prymnesiophytes and diatoms) accounted for 9 to $14 \%$; and $9^{\prime}$-cis-neoxanthin (chlorophytes) accounted for 0 to $8 \%$. Iron addition shifted phytoplank- 
Table 3. Normalized response (the ratio of iron-added at $t_{\text {final }}$ : control at $\left.t_{\text {final }}\right)$, for chl $a_{1}$, nitrate $\left(\mathrm{NO}_{3}{ }^{-}\right)$drawdown, particulate organic carbon (POC), particulate organic nitrogen (PON), and carotenoid pigments for each experiment. For example, a normalized response in chlorophyll of 1.5 indicates $50 \%$ more chlorophyll in iron-added replicates relative to controls. Carotenoid pigments are reported for the same $t_{\text {final }}$ as POC/PON measurements (see Table 2). Abbreviations and associated taxa for pigments are as follows: 19'-butanoyloxyfucoxanthin (19-but; pelagophytes and chrysophytes), fucoxanthin (Fuc; diatoms), 19'-hexanoyloxyfucoxanthin (19-hex; prymnesiophytes and diatoms), chlorophyll $c_{3}$ (Chl $c_{3}$ i prymnesiophytes and diatoms), 9'-cis-neoxanthin (Neo; chlorophytes), and total carotenoids (Car tot) are presented. The last 2 rows indicate micromoles of nitrate used per day in control and iron-added $(+\mathrm{Fe})$ experiments (nd: no data)

\begin{tabular}{|c|c|c|c|c|c|c|c|c|c|c|}
\hline Expt & $03-1$ & $03-2$ & $03-3$ & $03-4$ & $04-1$ & $04-2$ & $04-3$ & $04-4$ & $04-5$ & $04-6$ \\
\hline \multicolumn{11}{|c|}{ Normalized response to $+\mathrm{Fe}$ at $t_{\text {final }}(+\mathrm{Fe}:$ control $)$} \\
\hline Chl a & 1.7 & 2.1 & 2.6 & 3.4 & 3.1 & 1.3 & 1.6 & 2.0 & 1.5 & 1.2 \\
\hline $\mathrm{NO}_{3}{ }^{-}$drawdown & 2.3 & 1.7 & 2.1 & 2.2 & 2.5 & 1.2 & 1.1 & 2.9 & 1.2 & 1.4 \\
\hline POC & 1.2 & 0.9 & 1.8 & 1.8 & 1.4 & 1.3 & 1.3 & 2.1 & 1.4 & nd \\
\hline PON & 1.0 & 1.9 & 1.7 & 1.5 & 0.9 & 1.2 & 1.0 & 1.9 & 1.0 & nd \\
\hline 19-but & 1.0 & 1.5 & 1.2 & 3.4 & 1.3 & 0.9 & 0.6 & 0.8 & 1.3 & nd \\
\hline Fuc & 1.3 & 2.0 & 2.6 & 4.5 & 2.6 & 1.3 & 1.3 & 1.9 & 2.0 & nd \\
\hline 19-hex & 1.0 & 1.4 & 1.6 & 2.9 & 1.5 & 0.9 & 1.0 & 1.3 & 1.7 & nd \\
\hline $\mathrm{Chl} C_{3}$ & 1.0 & 2.1 & 1.6 & 2.6 & 2.2 & 1.3 & 1.9 & 1.5 & 2.0 & nd \\
\hline Neo & 2.4 & 3.5 & 3.1 & 5.9 & 4.9 & 0.9 & 1.1 & 4.9 & 2.9 & nd \\
\hline Car tot & 1.4 & 2.1 & 2.0 & 3.8 & 2.5 & 1.0 & 1.2 & 2.1 & 2.0 & nd \\
\hline \multicolumn{11}{|l|}{$\mathrm{NO}_{3}^{-}$used $\mathrm{d}^{-1}$} \\
\hline Control & 0.23 & 0.48 & 0.32 & 0.56 & 0.37 & 0.69 & 1.33 & 0.36 & 0.60 & 0.17 \\
\hline$+\mathrm{Fe}$ & 0.53 & 0.82 & 0.68 & 1.21 & 0.90 & 0.82 & 1.49 & 1.06 & 0.88 & 0.25 \\
\hline
\end{tabular}

ton community structure relative to controls (Table 3). The most noted (and consistent) changes in response to iron addition were in fucoxanthin (up to 4.5-fold more abundant), 9'-cis-neoxanthin (up to 5.9-fold more abundant), and chl $c_{3}$ (up to 2.6-fold more abundant). Changes in actual cell numbers, not only chl $a$ and carotenoid pigments, were confirmed by microscopy of formalin-preserved samples. Microscopy results for 5 of our 10 experiments are shown in Table 4.

Experiments lasted between 1 and $4 \mathrm{~d}_{\text {; }}$ the rate of nitrate depletion being a main factor determining the duration. When nitrate was depleted in bottle incubations, chl a typically began to decline and the experiment was terminated ( $t_{\text {final }}$ parameters recorded). Two general patterns were observed: (1) no or little change in chl $a$ in controls and an increase of chl $a$ in ironadded experiments (Fig. 3); and, more commonly, (2) an increase of chl $a$ in controls, but greater increase of chl $a$ in iron-added experiments (Fig. 4). The normali- zed response of phytoplankton chl $a$ to iron addition ranged between 1.2- and 3.4-fold (Table 3) and was found to be related to both initial nitrate and dissolved iron concentrations (Fig. 5). The phytoplankton response to iron addition was largest when nitrate was high and iron was low, e.g. $>1 \mu \mathrm{mol}$ nitrate $\mathrm{l}^{-1}$ and $<0.3 \mathrm{nmol} \mathrm{Fe} \mathrm{l}^{-1}$ (Figs. 3c \& 5). Under these conditions, dissolved iron was low enough that phytoplankton responded to iron addition, and nitrate was available long enough to observe the effect of iron addition. The response to iron addition was smaller when both nitrate and iron were low, e.g. $\leq 1 \mu \mathrm{mol}$ nitrate $\mathrm{l}^{-1}$ and $\leq 0.2 \mathrm{nmol} \mathrm{Fe}^{-1}$ (Figs. 4a \& 5), or when both nitrate and iron were high, e.g. $>1 \mu \mathrm{mol}$ nitrate $\mathrm{l}^{-1}$ and $>0.3 \mathrm{nmol}$ $\mathrm{Fe} \mathrm{l}^{-1}$ (Figs. 4c \& 5). In the former case (low nitrate and iron; Fig. 4a), nitrate in iron-added replicates depleted quickly, before a larger phytoplankton response could occur. In the latter case (high nitrate and iron; Fig. 4c), ambient dissolved iron was higher in concentration,

Table 4. Estimated phytoplankton cell counts (cells ml ${ }^{-1}$ ) at $t_{0}$ and $t_{x}$ in control (C) and iron addition (+Fe) experiments for 03-1 through 03-4 and 04-1. $t_{x}(\mathrm{~d})$ is indicated for each column. The category 'flagellates' includes both heterotrophic and autotrophic flagellates, which could not be discerned under light microscopy

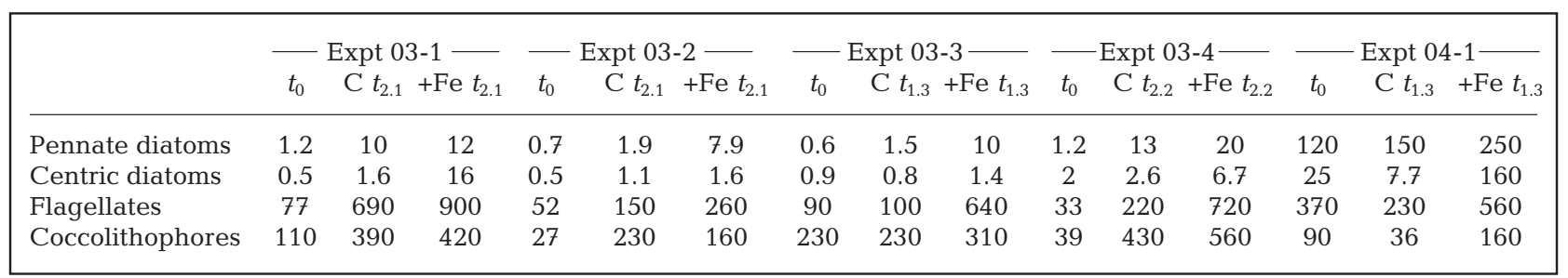



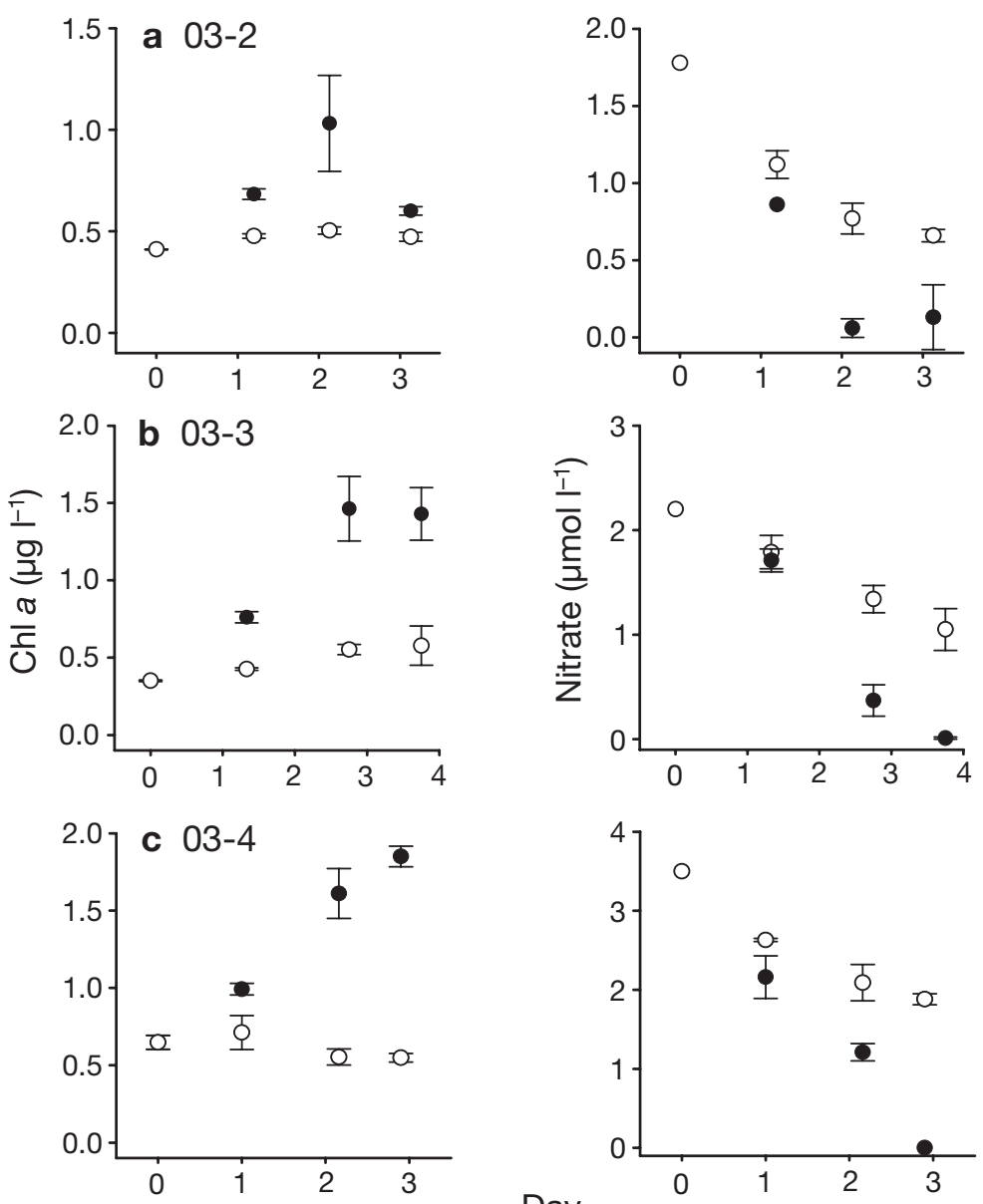

\section{Day}

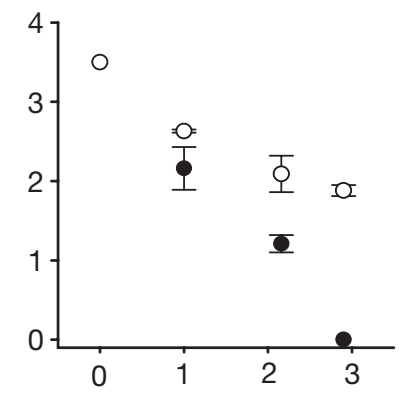

Fig. 3. Phytoplankton chl a $\left(\mu \mathrm{g}^{-1}\right)$ and nitrate $\left(\mu \mathrm{mol} \mathrm{l}^{-1}\right)$ from select incubation experiments (all July 2003) that exhibited a strong response to iron addition: (a) Expt 03-2, (b) Expt 03-3, and (c) Expt 03-4. (O) values from control experiments, $(\bullet)$ values from iron addition experiments. Error bars represent $1 \mathrm{SD}(\mathrm{n}=3)$. Note different scales on both $x$ - and $y$-axes

nitrate was only depleted slightly faster in iron-added replicates compared to controls, and iron addition was less important for phytoplankton growth.

\section{DISCUSSION}

\section{Differences between the southern CCS and HNLC regimes}

In comparison to reports of similar experiments conducted in oceanic and coastal HNLC regimes, the outcome of our iron addition grow-out experiments in the southern CCS coastal transition zone had some similarities and differences. The phytoplankton community response to iron addition varied-the results from some experiments resembled those conducted in oceanic (Martin \& Fitzwater 1988) and coastal HNLC regions (Hutchins et al. 1998), where phytoplankton chl a in iron-added experiments increased, while chl $a$ in control experiments changed very little (Fig. 3). Also similar to experiments in HNLC regimes, nitrate was depleted in ironadded replicates and to a lesser degree in control replicates, with an accompanying increase in POC and PON. The iron addition versus control differences in nitrate depletion in these experiments were varied, at times small (e.g. 1.1-fold more nitrate depleted in iron-added replicates), but at times relatively high (e.g. 2.9-fold more nitrate depleted in iron-added replicates; Table 3). The patterns (not magnitude) of chl a response and nitrate depletion in our studies were somewhat comparable to HNLC central California experiments which were described as being moderately iron-limited and ironstressed, as opposed to being severely iron-limited (Hutchins et al. 1998).

There were, however, striking differences between our iron addition experiments in the southern CCS and previously published work from coastal HNLC regimes, in terms of the duration and magnitude of the phytoplankton response to iron. The duration of the phytoplankton response in our southern CCS grow-out experiments was between 1.1 and $3.0 \mathrm{~d}$, with a chl a response ranging from 1.2- to 3.4 -fold the control values (Table 3 ), while in HNLC central California coastal waters and in the Peru Upwelling EBC the phytoplankton response ranged from 3 to $4 \mathrm{~d}$ in duration and was as high as $~ 3$ - to 5 -fold control values (Hutchins et al. 1998, 2002). The relatively shorter duration of the phytoplankton response to iron addition and the relatively low chl a response in the southern CCS were likely due to the lower concentrations of, and therefore more rapid depletion of, nitrate relative to HNLC regimes. In addition, relatively low concentrations of orthosilicic acid in our experiments might have resulted in co-limitation of diatoms. With respect to a deep water orthosilicic acid:nitrate ratio in the southern CCS region of $\sim 1.25$ (mean at $200 \mathrm{~m}$ from 1985 to 2005 CalCOFI database), orthosilicic acid concentrations were initially 11 to $53 \%$ depleted in 9 of our 10 experiments.

The summertime southern CCS is clearly not a conventional HNLC regime. During our study, the mesotrophic southern CCS coastal transition zone where we observed iron limitation had $<1 \mu \mathrm{g} \mathrm{chl} \mathrm{a} \mathrm{l}^{-1}$ and less 
than $\sim 4 \mu \mathrm{mol}$ nitrate $\mathrm{l}^{-1}$, while oceanic and coastal

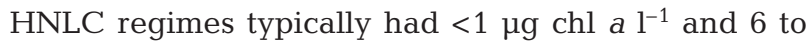
$25+\mu \mathrm{mol}$ nitrate $\mathrm{l}^{-1}$. Upon iron addition in HNLC regimes, chl a often exceeds $10 \mu \mathrm{g}$ chl a $\mathrm{l}^{-1}$, nitrate is depleted to $10-20 \mu \mathrm{mol} \mathrm{l} \mathrm{l}^{-1}$, POC and PON approach values of 100 and $10 \mu \mathrm{mol} \mathrm{l^{-1 }}$, respectively, and diatom concentrations approach 1000 to $>10000$ cells $\mathrm{ml}^{-1}$ (e.g. Martin \& Fitzwater 1988, Hutchins et al. 1998, 2002). In contrast, the iron addition response from our southern CCS incubation experiments was about an

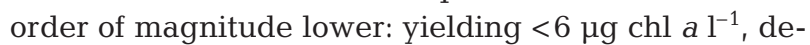
pletions of 1.0 to $3.5 \mu \mathrm{mol}$ nitrate $\mathrm{l}^{-1}, \sim 15$ to $20 \mu \mathrm{mol}$ POC $1^{-1}$, 2 to $5 \mu \mathrm{mol} \mathrm{PON}^{-1}$, and diatom concentrations were in the range of 10 to several hundred cells $\mathrm{ml}^{-1}$ (Tables 2 \& 4).

Dissolved iron was relatively low at the locations of our experiments in the southern CCS, but not as low as
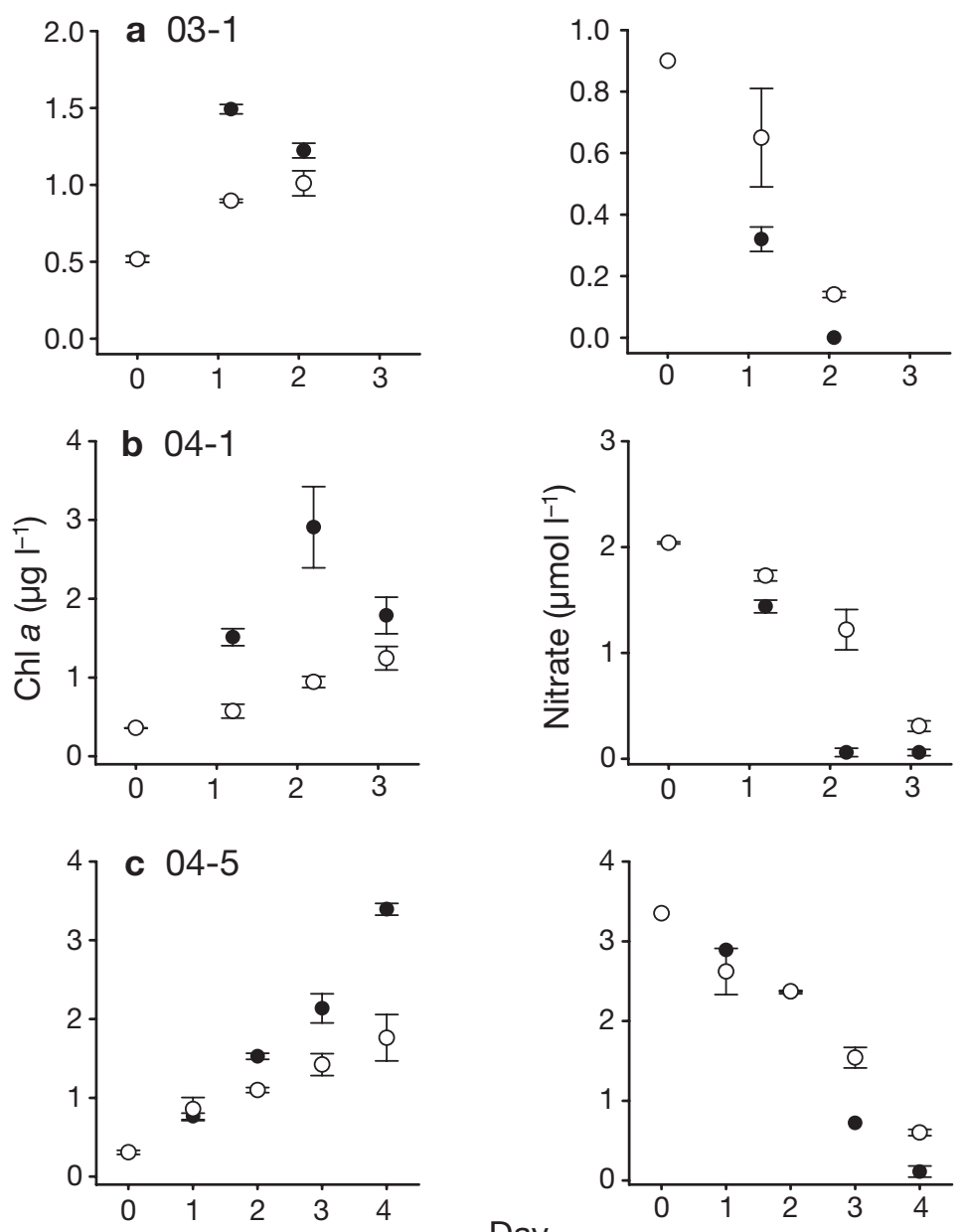

Fig. 4. Phytoplankton chl a $\left(\mu \mathrm{g} \mathrm{l}^{-1}\right)$ and nitrate $\left(\mu \mathrm{mol} \mathrm{l}^{-1}\right)$ from select incubation experiments that exhibited a more subtle response to iron addition: (a) Expt 03-1, July 2003, (b) Expt 04-1, July 2004, and (c) Expt 04-5, July 2004. (O) Values from control experiments, $(\bullet)$ values from iron addition experiments. Error bars represent $1 \mathrm{SD}(\mathrm{a}: \mathrm{n}=3 ; \mathrm{b} \& \mathrm{c}: \mathrm{n}=2)$. Note different scales on both $x$ - and $y$-axes typically observed in iron-limited HNLC regimes. Dissolved iron $(<0.2 \mu \mathrm{m})$ in oceanic and coastal HNLC regimes is $<0.2 \mathrm{nmol} \mathrm{l}^{-1}$, sometimes approaching $20 \mathrm{pmol} \mathrm{l}^{-1}$, the detection limit of most methods (Johnson et al. 1997). In oceanic regions, it is believed that dissolved iron is low due to the large distance from continental sources of iron (Fung et al. 2000), although whether the primary source of iron to the open ocean is aeolian or upwelling remains a debate (Elrod et al. 2004). Coastal phytoplankton and iron geochemistry studies off the central and northern California coast have observed iron limitation to occur during summer upwelling months when iron was scarce relative to macronutrients (Hutchins et al. 1998). The continental shelf has been identified as a key variable that influences the concentration of dissolved iron and determines whether iron limitation occurs in coastal winddriven upwelling water masses, within $10 \mathrm{~km}$ of shore. A broad continental shelf (e.g. Cape Mendocino, 20 to $50 \mathrm{~km}$ wide) is thought to be able to accumulate iron delivered in wintertime fluvial depositions and provide a reservoir of reduced and dissolved iron (Johnson et al. 1999). Upwelled water masses along broad shelves were reported to have 0.3 to $10 \mathrm{nmol} \mathrm{Fe} l^{-1}$ and up to $15 \mu \mathrm{mol}$ nitrate $\mathrm{l}^{-1}$, and were found to be iron-replete with respect to phytoplankton nutrient requirements (Bruland et al. 2001). In regions of narrower shelf widths (e.g. Big Sur, 2 to $3 \mathrm{~km}$ wide), upwelled water masses had lower dissolved iron con-

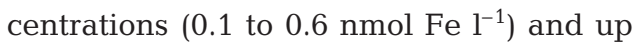
to $15 \mu \mathrm{mol}$ nitrate $\mathrm{l}^{-1}$ (Bruland et al. 2001), and were locations where phytoplankton were observed to be iron-limited (Hutchins et al. 1998).

The continental shelf bordering the southern CCS is relatively broad in comparison to that of central and northern $\mathrm{Ca}$ lifornia, $\sim 50 \mathrm{~km}$ wide in the Santa Barbara Basin (northeastern portion of the CalCOFI sampling region) and $\sim 10 \mathrm{~km}$ wide elsewhere (as defined by the $200 \mathrm{~m}$ isobath, see Fig. 1). Along the coastline of the southern CCS, the supply of iron is likely adequate due to the broad continental shelf (nearshore dissolved iron concentrations in the southern CCS were in excess of $1 \mathrm{nmol} \mathrm{l}^{-1}$ in July 2003 and 2004; A. King and K. Barbeau unpubl. data). However, in the case of iron limitation in the southern CCS, the relationship between iron supply and the width of the continental shelf might not be critical. Our observations of 


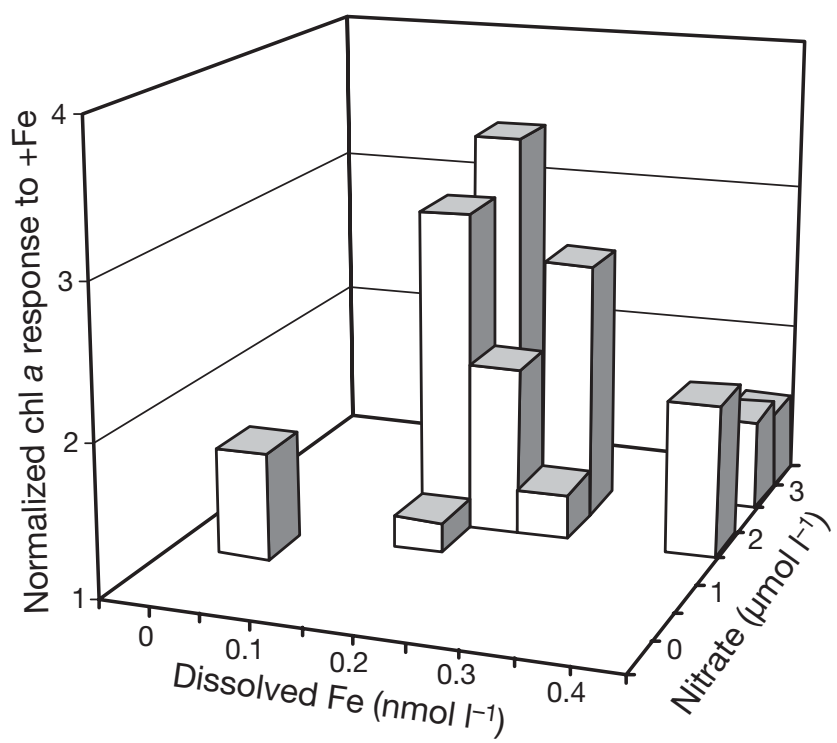

Fig. 5. Normalized responses of phytoplankton in iron addition experiments are summarized relative to initial nitrate and dissolved iron concentrations (nitrate binned to $0.5 \mu \mathrm{mol} \mathrm{l}^{-1}$ units, dissolved Fe binned to $0.05 \mathrm{nmol}^{-1}$ units). Normalized response to iron addition ( $y$-axis) is the ratio of chl $a$ in iron addition experiments to chl $a$ in controls at $t_{\text {final }}$ (Table 3 ). The effect of iron addition on phytoplankton growth appears to be strongest under high-nitrate, low-iron conditions (middle of figure). In contrast, the response to iron addition was weaker under low-nitrate, low-iron conditions (left portion of figure) and high-nitrate, high-iron conditions (right portion of figure)

iron limitation were not coastal, but primarily within the coastal transition zone of the southern CCS, some 50 to $200 \mathrm{~km}$ offshore. In this region of the southern CCS, the supply of iron may be less influenced by benthic sources because the seafloor depth in the coastal transition zone ranges from 570 to $4000 \mathrm{~m}$. In the coastal transition zone, wind stress curl might force upwelling offshore (Chelton 1982), where a continental shelf source of iron does not exist. Or, alternatively, the coastal transition zone might be composed of coastal upwelling water masses advected offshore from the north or east, which may be relatively depleted in iron relative to nitrate due to biological uptake (e.g. Firme et al. 2003).

\section{Is this iron limitation?}

The dissolved iron concentrations at our experimental stations (0.05 to $0.46 \mathrm{nmol} \mathrm{Fe}{ }^{-1}$; see Table 2) were near estimates of growth half-saturation constants $\left(K_{\mu}\right.$ the concentration at which the growth rate is at half of the maximum growth rate). Field studies have reported community $K_{\mu}$ to be $0.12 \mathrm{nmol} \mathrm{Fe} \mathrm{l}^{-1}$ in the equa-

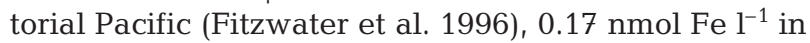

the Humboldt Current, Peru, and $0.26 \mathrm{nmol} \mathrm{Fe} \mathrm{l}^{-1}$ in the Peru Upwelling (Hutchins et al. 2002). Growth half-saturation constants for iron for an assortment of diatoms recently summarized by Sarthou et al. (2005) were $0.35 \pm 0.44 \mathrm{nmol} \mathrm{Fe}^{-1}(\mathrm{n}=11$, range $=0.59 \mathrm{pmol}$ $\mathrm{Fe} \mathrm{l}^{-1}$ to $1.14 \mathrm{nmol} \mathrm{Fe} \mathrm{l}^{-1}$ ). Half-saturation constants for iron uptake $\left(K_{\mathrm{s}}\right)$ may be a more appropriate metric for our comparison, and have been reported to be $0.034 \mathrm{nmol} \mathrm{Fe} \mathrm{l}^{-1}$ for the tropical Pacific and $0.22 \mathrm{nmol}$ $\mathrm{Fe}^{-1}$ in the north central Pacific (Price et al. 1994). $K_{\mathrm{s}}$ is the concentration at which nutrient uptake rate is at half of the maximum uptake rate. $K_{\mathrm{s}}$ measurements are typically made over the time scale of hours, while $K_{\mu}$ measurements are typically made over the time scale of days, and, at steady state, $K_{\mathrm{u}}$ begins to approach $K_{\mathrm{s}}$ (Morel 1987). Our measured dissolved iron concentrations for the southern CCS are within the upper range of the above-referenced $K_{\mu}$ and $K_{\mathrm{s}}$ estimates and could potentially limit phytoplankton from achieving its maximum growth rate.

Uptake half-saturation constants of nitrate, phosphate, and orthosilicic acid for an assortment of diatoms were $1.6 \pm 1.9 \mu \mathrm{mol}$ nitrate $\mathrm{l}^{-1}(\mathrm{n}=35), 0.24 \pm$ $0.29 \mu \mathrm{mol}$ phosphate $\mathrm{l}^{-1}(\mathrm{n}=14)$, and $3.9 \pm 5.0 \mu \mathrm{mol}$ orthosilicic acid $l^{-1}(\mathrm{n}=25)$ (Sarthou et al. 2005). $K_{\mathrm{s}}$ for a variety of cultured oceanic and neritic diatoms, coccolithophores, and flagellates ranged between 0.1 and $10.3 \mu \mathrm{mol}$ nitrate $^{-1}$ (Eppley et al. 1969). At our experimental stations, nitrate $\left(0.9\right.$ to $\left.3.5 \mu \mathrm{mol} \mathrm{l}^{-1}\right)$, phosphate $\left(0.30\right.$ to $\left.0.57 \mu \mathrm{mol}^{-1}\right)$, and orthosilicic acid ( 0.3 to $2.2 \mathrm{~mol} \mathrm{l}^{-1}$ ) concentrations were within the respective $K_{\mathrm{s}}$ ranges and could potentially have been co-limiting nutrients. While these comparisons are suggestive, caution should be exercised in extending results from culture studies to our experiments with natural communities in which diatoms were present, but not dominant (as indicated by HPLC pigment analysis and microscopy).

In the southern CCS, the case for iron limitation is most distinctly exemplified by Expts 03-2, 03-3, and 03-4 (Fig. 3). In these experiments, chl $a$ in control experiments remained low or unchanged, while chl a increased in iron-added replicates, as previously documented in HNLC regimes. The phytoplankton community in iron-amended experiments was shifted towards diatoms and chlorophytes (as indicated by the pigments fucoxanthin and neoxanthin in Table 3). Nitrate was depleted more quickly in iron-added experiments, while nitrate in controls was somewhat depleted. This general pattern was somewhat reflected in larger POC and PON accumulation in iron-added experiments. The type of results described above supports the contention that at those stations, iron was a growth ratelimiting nutrient for the phytoplankton community, or for some segment of the community (e.g. Cullen 1991). 
The case for iron limitation is less clear in the other experiments we conducted in the southern CCS (e.g. Fig. 4). In these experiments, Expts 03-1 and 04-1 through 04-6, chl a increased in control experiments, but, a larger increase was observed and a larger standing stock accumulated with iron-addition. It is quite evident that in these experiments the addition of iron had some influence on phytoplankton growth and community structure (Table 2). The differences in observed chl a patterns between experiments in Fig. 3 versus Fig. 4 might have been due to differing grazing pressure, and thus control of standing stock. Alternatively, our experiments might have been subject to bottle effects related to grazer exclusion and trace metal contamination (Cullen 1991, Martin \& Fitzwater 1988).

Our study and previous studies in the southern CCS (e.g. Eppley et al. 1979) indicate that nitrate is a biomass-limiting nutrient and iron is a growth ratelimiting nutrient for at least some components of the phytoplankton community. The related concept of multiple resource co-limitation has recently been reviewed by Arrigo (2005). In the context of kinetic uptake, the concentration of dissolved iron (0.05 to 0.46 $\mathrm{nmol} \mathrm{Fe} \mathrm{l}^{-1}$ ) at our experimental stations was likely lower than the concentration required for maximum growth, but higher than the concentration at which growth is zero. As a biomass-limiting nutrient, the supply of nitrate in the experiments determines total new production. Once the supply of nitrate is exhausted in our experiments, regardless of how much iron is added, new production is halted and the community relies on recycled $\mathrm{N}$ as a nutrient source. Whether a community is growth rate-limited by iron is conceptually and ecologically significant in nitratelimited upwelling systems like the southern CCS. For example, if iron and nitrate are replete during upwelling (e.g. $5 \mu \mathrm{mol}$ nitrate $\mathrm{l}^{-1}$ and 2 nmol $\mathrm{Fe} \mathrm{l}^{-1}$ ), the phytoplankton community would presumably be dominated by large cells, net growth would be high and a bloom would occur over a relatively short time scale, until 1 of the 2 nutrients is depleted. The onset and fall of the bloom would be determined by a number of factors, including temperature, light, recycling rates of $\mathrm{N}$ or iron, or microor macrozooplankton grazing. If nitrate is replete relative to iron in upwelled waters (e.g. $5 \mu \mathrm{mol}$ nitrate $\mathrm{l}^{-1}$ and $0.05 \mathrm{nmol} \mathrm{Fe} \mathrm{l}^{-1}$ ), the phytoplankton community would be composed of smaller cell types, growth would be somewhat balanced by grazing, and, in contrast, iron would limit the growth of the larger cells, and subsequently their biomass (Bruland et al. 2001). In this case, it is the concentration of iron that would limit total new production over time. If iron is a growth rate-limiting nutrient and not a biomass-limiting nutrient, our results suggest that the community would likely consist of diverse taxa, phytoplankton growth would be between the iron-replete and iron-limited systems (not maximal and not zero), and iron availability would limit nitrate utilization (directly or indirectly). Provided that iron remains available, this scenario would continue until nitrate is depleted (this is what is apparently occurring in our incubation experiments). Assuming a given upwelled nitrate concentration in a system that is biomass limited by nitrate, total new production would be the same regardless of whether iron is growth ratelimiting or replete. A key difference would be that new production under conditions in which iron is growth rate-limiting would occur over a longer period of time (Fig. 6), extending surface nitrate residence time, possibly expanding the horizontal distribution of nitrate as a result of mixing or transport. This could also lend to the maintenance of mesotrophic regimes, an intermediate ecosystem state between low new production oligotrophic systems and high new production, boomand-bust eutrophic systems. On a global scale, mesotrophic regimes, designated as oceanic regions with between 0.1 and $1 \mu \mathrm{g} \mathrm{chl} \mathrm{al}^{-1}$, account for roughly half of the phytoplankton carbon fixation (Behrenfeld \& Falkowski 1997).

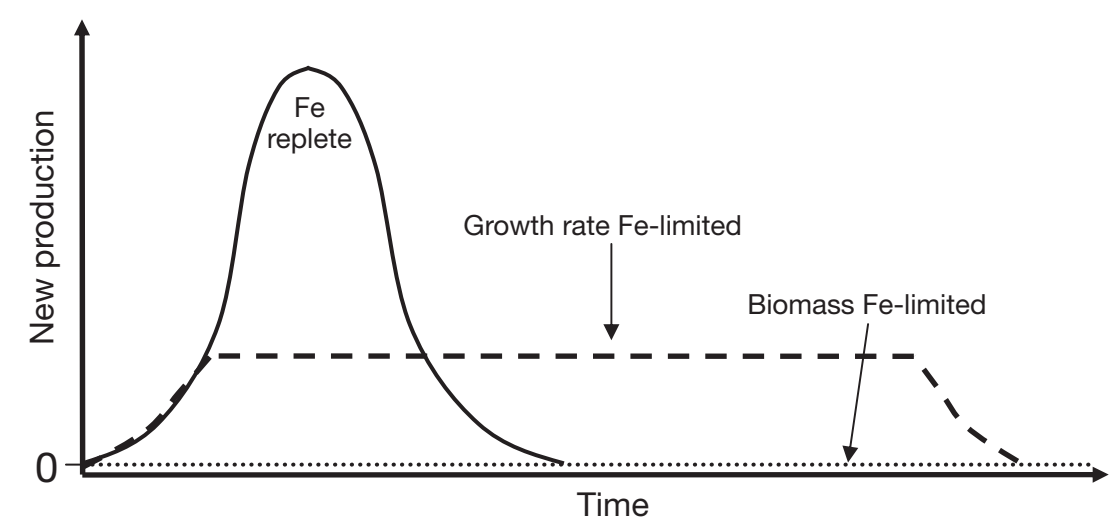

Fig. 6. A simplified conceptual model of new production over time in 3 nitrate-limited scenarios in which initial nitrate concentrations are equal. The solid line represents new production in an iron-replete system; the dashed line represents new production in a system where iron is a growth rate-limiting nutrient; the dotted line represents new production in a system where iron is a biomass-limiting nutrient (e.g. highnutrient, low-chlorophyll regime). New production is higher and occurs over a relatively short period of time in the iron-replete scenario, while new production is lower and occurs over a longer time period in the growth rate iron limitation. Note that total new production levels in both situations in which iron is replete and growth rate-limiting are equivalent because nitrate is the biomass-limiting nutrient. Units on the $x$ - and $y$-axes are arbitrary 


\section{Historical context and conclusions}

CalCOFI time-series measurements made over the last $20 \mathrm{yr}$ indicate that the presence of unused nitrate in surface waters is relatively common. Between 1985 and 2005 (all seasons), from 5803 stations on $>80$ CalCOFI research cruises in the southern CCS, 989 of the stations had $\geq 1 \mu^{m o l ~} \mathrm{l}^{-1}$ nitrate in surface waters, of which 421 stations were in the coastal transition zone ( 50 to $250 \mathrm{~km}$ offshore). Of these coastal transition zone stations that had $>1 \mu \mathrm{mol} \mathrm{l^{-1 }}$ nitrate, about two-thirds also had $\leq 1 \mu \mathrm{g} \mathrm{chl} \mathrm{a} \mathrm{l}^{-1}$ (266 stations); an observation which could possibly be explained by iron limitation. Although macronutrients may not be persistent in surface waters of the southern CCS (i.e. existing unused on the time scale of months as in HNLC regimes), it does appear that macronutrients are often present in surface waters, implying that there may be a relatively consistent supply of macronutrients and a temporal decoupling between this supply and phytoplankton utilization and growth. Based on the relatively low concentration of dissolved iron $\left(<0.45 \mathrm{nmol} \mathrm{l}^{-1}\right)$, the distant proximity of the coastal transition zone to shelf sources of iron, and the results from our iron addition grow-out experiments, we infer that iron likely plays a role in the discrepancy between unused nitrate and low phytoplankton biomass observed in the $20 \mathrm{yr}$ dataset. However, at this time, we cannot rule out alternate factors that may be preventing phytoplankton from utilizing nitrate, separately or in concert with iron limitation, such as (proximate) grazing control or light limitation.

The biogeochemical consequences of iron limitation in the southern CCS may not appear to be dramatic when compared to iron limitation in HNLC regimes. The amount of unused macronutrients present and the increase in chl a after iron addition were much lower in the southern CCS relative to similar observations from HNLC regimes. Regardless, the degree of iron limitation observed in this study could have significant implications for biogeochemical and ecological processes. During times of upwelling, variability in the supply of iron could influence the type of phytoplankton community that develops and the spatial and temporal patterns in phytoplankton distribution. Santa Ana winds, seasonal offshore gusts occurring in the southwestern United States that often transport large amounts of terrestrial material offshore ( $\mathrm{Hu} \& \mathrm{Liu}$ 2003), are one such source of variability in the supply of iron to the southern CCS. The supply of iron can also modulate phytoplankton nitrate utilization (directly or indirectly) and, thus, control the residence time and distribution of upwelled nitrate and other micro- and macronutrients. This could create situations in which nitrate may be more or less subject to mixing or trans- port. The above predictions may result in small, but significant, aberrations in primary production and biogeochemical cycling of nutrients in the southern CCS, which might only be quantified or observed over long time scales.

Acknowledgements. We thank B. Hopkinson, J. Nunnery, S. Reynolds, K. Roe, the CalCOFI research group, especially R. Goericke, J. Wilkinson, D. Wolgast, and the officers and crews of the RV 'New Horizon' and 'David Starr Jordan', for assistance in collecting and analyzing data. E. Venrick provided assistance in phytoplankton identification. We also thank 2 anonymous reviewers for insightful comments and suggestions. This research was funded by NASA NIP Grant NAG5-12535 and LTER NSF/OCE-0417616.

\section{LITERATURE CITED}

Arrigo KR (2005) Marine microorganisms and global nutrient cycles. Nature 437:349-355, doi:10.1038/nature04158

Behrenfeld MJ, Falkowski PG (1997) Photosynthetic rates derived from satellite-based chlorophyll concentration. Limnol Oceanogr 42:1-20

Bowie AR, Achterberg EP, Fauzi R, Mantoura C, Worsfold PJ (1998) Determination of sub-nanomolar levels of iron in seawater using flow injection with chemiluminescence detection. Anal Chim Acta 361:189-200

Bruland KW, Rue EL, Smith GJ (2001) Iron and macronutrients in California coastal upwelling regimes: implications for diatom blooms. Limnol Oceanogr 46:1661-1674

Chelton DB (1982) Large-scale response of the California Current to forcing by the wind stress curl. Calif Coop Ocean Fish Invest Rep 23:130-148

Cullen JJ (1991) Hypotheses to explain high-nutrient conditions in the open sea. Limnol Oceanogr 36:1578-1599

de Baar HJW, Buma AGJ, Nolting RF, Cadee GC, Jacques G, Treguer PJ (1990) On iron limitation of the Southern Ocean: experimental observations in the Weddell and Scotia Seas. Mar Ecol Prog Ser 65:105-122

Elrod VA, Berelson WM, Coale KH, Johnson KS (2004) The flux of iron from continental shelf sediments: a missing source for global budgets. Geophys Res Lett 31:L12307, doi:10.1029/2004GL020216

Eppley RW, Holm-Hansen O (1986) Primary production in the Southern California Bight. In: Eppley RW (ed) Plankton dynamics of the Southern California Bight. Lecture notes on coastal and estuarine studies, Vol 15. Springer-Verlag, Heidelberg, p 176-215

Eppley RW, Rangers JN, McCarthy JJ (1969) Half-saturation constants for uptake of nitrate and ammonium by marine phytoplankton. Limnol Oceanogr 14:912-920

Eppley RW, Renger EH, Harrison WG (1979) Nitrate and phytoplankton production in Southern California coastal waters. Limnol Oceanogr 24:483-494

Firme GF, Rue EL, Weeks DA, Bruland KW, Hutchins DA (2003) Spatial and temporal variability in phytoplankton iron limitation along the California coast and consequences for $\mathrm{Si}, \mathrm{N}$, and $\mathrm{C}$ biogeochemistry. Global Biogeochem Cycles 17:1016, doi:10.1029/2001GB001824

Fitzwater SE, Coale KH, Gordon M, Johnson KS, Ondrusek ME (1996) Iron deficiency and phytoplankton growth in the equatorial Pacific. Deep-Sea Res II 43:995-1015

Fitzwater SE, Johnson KS, Elrod VA, Ryan JP, Coletti LJ, Tanner SJ, Gordon RM, Chavez FP (2003) Iron, nutrient and 
phytoplankton biomass relationships in upwelled waters of the California coastal system. Cont Shelf Res 23: 1523-1544

Fung IY, Meyn AK, Tegen I, Doney SC, John JG, Bishop JKB (2000) Iron supply and demand in the upper ocean. Global Biogeochem Cycles 14:281-295

Goericke R, Montoya JP (1998) Estimating the contribution of microalgal taxa to total chl a in the field-variations of pigment ratios under nutrient- and light-limited growth. Mar Ecol Prog Ser 169:97-112

Hayward TL, Venrick EL (1998) Nearsurface pattern in the California Current: coupling between physical and biological structure. Deep-Sea Res II 45:1617-1638

$\mathrm{Hu}$ H, Liu WT (2003) Oceanic thermal and biological responses to Santa Ana winds. Geophys Res Lett 30:1596, doi:10.1029/2003GL017208

Hutchins DA, Bruland KW (1998) Iron-limited diatom growth and $\mathrm{Si}: \mathrm{N}$ uptake ratios in a coastal upwelling regime. Nature 393:561-564

Hutchins DA, DiTullio GR, Zhang Y, Bruland KW (1998) An iron limitation mosaic in the California upwelling regime. Limnol Oceanogr 43:1037-1054

Hutchins DA, Hare CE, Weaver RS, Zhang Y and 11 others (2002) Phytoplankton iron limitation in the Humboldt Current and Peru Upwelling. Limnol Oceanogr 47:997-1011

Johnson KS, Gordon RM, Coale KH (1997) What controls dissolved iron concentrations in the world ocean? Mar Chem $57: 137-161$

Johnson KS, Chavez FP, Friederich GE (1999) Continentalshelf sediment as a primary source of iron for coastal phytoplankton. Nature 398:697-700

Johnson KS, Chavez FP, Elrod VA, Fitzwater SE, Pennington JT, Buck KR, Waltz PM (2001) The annual cycle of iron and the biological response in the central California coastal waters. Geophys Res Lett 28:1247-1250

Johnson KS, Boyle E, Bruland K, Coale K and 31 others (2007) Developing standards for dissolved iron in seawater. Eos Trans Am Geophys Union 88:131-132

Jones BH, Brink KH, Dugdale RC, Stuart DW, Vanleer JC, Blasco D, Kelley JC (1983) Observations of a persistent upwelling center off Point Conception, California, Part A. In: Suess E, Thiede J (eds) Coastal upwelling, its sediment

Editorial responsibility: Otto Kinne (Editor-in-Chief) Oldendorf/Luhe, Germany record. Plenum, New York, p 37-60

Landry MR, Barber RT, Bidigare RR, Chai F and 9 others (1997) Iron and grazing constraints on primary production in the central equatorial Pacific: an EqPac synthesis. Limnol Oceanogr 42:405-418

Lohan MC, Aguilar-Islas AM, Franks RP, Bruland KW (2005) Determination of iron and copper in seawater at $\mathrm{pH} 1.7$ with a new commercially available chelating resin, NTA Superflow. Anal Chim Acta 530:121-129

Lynn RJ, Simpson JJ (1987) The California Current System: the seasonal variability of its physical characteristics. J Geophys Res 92(C12):12947-12966

Martin JH, Fitzwater SE (1988) Iron deficiency limits phytoplankton growth in the north-east Pacific subarctic. Nature 331:341-343

Martin JH, Gordon MR, Fitzwater S, Broenkow WW (1989) VERTEX: phytoplankton/iron studies in the Gulf of Alaska. Deep-Sea Res 36:649-680

Miller CB, Frost BW, Wheeler PA, Landry MR, Welschmeyer N, Powell TM (1991) Ecological dynamics in the subarctic Pacific, a possibly iron-limited ecosystem. Limnol Oceanogr 36:1600-1615

Morel FMM (1987) Kinetics of nutrient uptake and growth in phytoplankton. J Phycol 23:137-150

Nelson CS (1977) Wind stress and wind stress curl over the California Current. NOAA Tech Rep NMFS-SSRF 714:1-87

Price NM, Ahner BA, Morel FMM (1994) The equatorial Pacific Ocean: grazer controlled phytoplankton populations in an iron-limited ecosystem. Limnol Oceanogr 39:520-534

Ryther JH, Dunston WM (1971) Nitrogen, phosphorus and eutrophication in the coastal marine environment. Science 171:1008-1112

Sarthou G, Timmermans KR, Blain S, Treguer P (2005) Growth physiology and fate of diatoms in the ocean: a review. $\mathrm{J}$ Sea Res 53:25-42

Strickland JDH, Parsons TR (1972) A practical handbook of sea-water analysis, 2nd edn. Bull Fish Res Board Can 167:1-311

Winant CD, Dorman CE (1997) Seasonal patterns of surface wind stress and heat flux over the Southern California Bight. J Geophys Res C102:5641-5653

Submitted: September 18, 2006; Accepted: February 15, 2007 Proofs received from author(s): June 23, 2007 